Vol. 3 No. 1 2020, Hal 61-81

\title{
MODEL PENGINTEGRASIAN \\ PENEGAKAN HUKUM PILKADA SERENTAK GUNA MEWUJUDKAN KEADILAN SUBSTANTIF \\ (Evaluasi Penegakan Hukum \\ Pilkada Serentak 2015-2020)
}

\author{
Agus Riwanto \\ Hukum Tata Negara dan Pascasarjana Ilmu Hukum \\ Fakultas Hukum Universitas Sebelas Maret Surakarta \\ Jl. Ir. Sutami No.36 A Kentingan Surakarta \\ agusriewanto@yahoo.com dan agusriwanto@staff.uns.ac.id
}

\begin{abstract}
Abstrak
Penelitian ini akan mengkaji dan mendalami tentang evaluasi praktik penegakan hukum dalam Pilkada Serentak 2015-2020 melalui berbagai pintu (justice in many rooms), yakni Bawaslu Propinsi/Kabupaten/Kota, Pengadilan Tata Usaha Negara, Pengadilan Negeri, Dewan Kehormatan Penyelenggara Pemilu dan Mahkamah Konstitusi. Akibatnya memicu ketidakpastian hukum dan berorientasi pada keadilan prosedural bukan keadilan substantif.

Penelitian ini adalah penelitian hukum normatif. Pendekatan yang digunakan adalah asas hukum, perundangan, dan konseptual. Teknik pengumpulan data dilakukan dengan metode studi pustaka. Teknis analisis data dengan menggunakan metode hermeneutika, yakni mendeskripsikan secara objektif dan sistematis isi norma dan praktiknya secara interaktif. Di masa mendatang (ius costituendum) diperlukan pengintegrasian (one roof system) dalam penegakan hukum Pilkada guna mencapai cita-cita keadilan substantif.

Operasionalisasi dari gagasan ini adalah mendisain ulang sistem penegakan hukum Pilkada melalui revitalisasi fungsi Bawaslu yang ada saat ini sebagai Badan Penyelesaian Hukum Pemilihan (BPHP) yang bersifat semi peradilan (quasi judiciary).

Adapun kewenangan Bawaslu untuk menyelesaian kasus pelanggaran administrasi, pelanggaran proses pemilihan, dan kode etik yang putusannya bersifat final dan mengikat. Sedangkan perselisihan hasil Pilkada diselesaikan melalui Mahkamah Agung sesuai ketentuan Pasal 24 UUD 1945 dan Pasal 157 Ayat (1) Undang-Undang Nomor 10 Tahun 2016 Tentang Pemilihan Gubernur,
\end{abstract}


Bupati dan Walikota. Maka kewenangan Bawaslu didesain lebih beroreintasi pada penegakan hukum dengan sanksi administrasi bukan pidana.

Kata Kunci: Pengintegrasian, penegakan hukum, keadilan substantif dan Pilkada

\begin{abstract}
This research will examine and explore the evaluation of law enforcement practices in the 2015-2020 Concurrent Elections through various doors (justice in many rooms), namely Election Supervisory Board Province/Regency/City, State Administrative Court, District Court, Honorary Board of Election Organizers and Constitutional Court. The result triggers legal uncertainty and is oriented towards procedural fairness rather than substantive justice.

This research is normative legal research. Research approach used is the principle of law, legislation, and conceptual. Data collection techniques are carried out using the library study method. Technical data analysis using hermeneutic methods, namely describing objectively and systematically the content of norms and practices interactively. In the future (ius costituendum) is needed integration (one roof system) in the enforcement of electoral law in order to achieve the ideals of substantive justice.

The operationalization of this idea is to redesign the electoral law enforcement system through the revitalization of Election Supervisory Board current function as a semi-judicial Judicial Settlement Agency.

Election Supervisory Board authority to complete cases of administrative violations, violations of the electoral process, and a code of conduct whose rulings are final and binding. While the dispute of election results is resolved through the Supreme Court in accordance with the provisions of Article 24 of the 1945 Constitution and Article 157 Paragraph (1) of Law Number 10 of 2016 concerning the Election of Governors, Regents and Mayors. Election Supervisory Board authority is designed to focus more on law enforcement with administrative sanctions instead of criminal.
\end{abstract}

Keywords: Integration, law enforcement, substantive justice and local elections

\section{Pendahuluan}

Pemilihan Kepala Daerah (Pilkada) Serentak merupakan amanat ketentuan Pasal 18 ayat (4) UUD 1945 yang menempatkan frasa "Demokratis" dalam melakukan pemilihan kepala daerah. Pembentuk UU No.32
Tahun 2004 Tentang Pemerintah Daerah beserta perubahannya yang terakhir diubah dengan UU No.10 Tahun 2016 Tentang Pemilihan Gubernur, Bupati dan Walikota (Selanjutnya disebut UU Pilkada) dimakani sebagai "pemilihan langsung" sebagaimana pemilihan Anggota DPR, DPD, 
DPRD Propinsi, DPRD Kabupaten / Kota dan pemilihan presiden dan wakil presiden (Asshiddiqie, 2002, hlm. 22).

Pilihan model Pilkada Serentak di Indonesia dilaksanakan secara bertahap sesuai bukan bersamaan waktunya di 542 daerah otonomi di Indonesia yang terdiri dari: 34 Provinsi; 415 Kabupaten, dan 93 Kota. Salah satu alasannya karena masa kerja kepala daerah di Indonesia tidak sama, sehingga Pilkada tidak dapat dilaksanakan dalam waktu yang sama dan dilaksanakan serentak secara bertahap.

Pilihan kebijakan politik hukum Pilkada Serentak di Indonesia dilaksanakan dalam 4 (empat) tahap yang masing-masing didasarkan pada akhir masa jabatan (AMJ) kepala daerah yang telah berlangsung pada tahun 2015, 2017, 2018 dan 2020 mendatangm yaitu:

a. Serentak Desember 2015 untuk Kepala Daerah yang AMJ Th. 2015 sd. Juni 2016;

b. Serentak Februari 2017 untuk Kepala Daerah yang AMJ Juli sd Desember 2016 dan Tahu 2017;

c. Serentak Juni 2018 untuk Kepala Daerah yang AMJ Tahun 2018 dan Tahun. 2019;

d. Serentak Tahun 2020 untuk hasil pemilihan Tahun 2015. Dalam penyelenggaraan Pemilu termasuk Pilkada isu yang utama yang memperoleh perhatian publik adalah terkait dengan sistem pemilu, managemen pemilu, penegakan hukum pemilu dan aktor pemilu. (Supriyanto, 2012, hlm. 211). Penegakan hukum pemilu merupakan mahkota untuk menggaransi terselenggaranya pemilu yang adil dan demokratis. Maka penegakan hukum pemilu ditujukan agar aktor pemilu dapat mematuhi aneka peraturan perundang-undangan

yang mengatur tentang Pemilu dan hak politik dan pilih masyarakat dapat diwujudkan. (Electoral Integrity Group, 2016).

Oleh karena itu dalam penegakan hukum pemilu yang hendak diwujudkan adalah keadilan Pemilu yang mengutamakan pada konsep keadilan substantif dalam proses penyelenggaraan antara aktor pemilu, yakni pemilih, peserta pemilu dan penyelenggara Pemilu.

Dalam mewujudkan keadilan Pemilu yang substantif tersebut diperlukan sistem penegakan hukum (due process of law), yakni suatu proses adil dan layak (fair and proper) sebagai dasar pengambilan tindakan. Tujuan utama dari due process of law adalah untuk memberikan jaminan terbaik bahwa proses penemuan fakta dalam penyelesaian sengketa juga mengakomodir kepentingan yang saling bertentangan diantara para pihak. Maka yang hendak dibangun, tidak hanya mengenai keberadaan suatu, melainkan juga memastikan mekanisme itu dapat berjalan secara patut dan layak. (Siregar, 2019, hlm. 299).

Due process of law yang patut dan layak itu haruslah dirancang secara demokratis 
pula, yakni substansi peraturan perundang-undangan yang memadai, lengkap dan tak multitafsir.

Diperlukan pula struktur penegak hukum pemilu, yakni Polisi, Jaksa, Hakim dan Badan Pengawas Pemilu (Bawaslu) yang berintegritas dan budaya hukum yang menyokongnya, yakni seberapa kuat masyarakat memiliki kesadaran hukum dalam berpartisipasi untuk menjadikan hukum sebagai paradigma dalam menyelesaikan semua aspek pelanggaran hukum dalam Pemilu.

Penyelenggaraan Pilkada di Indonesia yang diintrodusir sejak tahun 2005-2013 melalui UU No.32 Tahun 2004 Tentang Pemerintah Daerah dan dilanjutkan dengan mengintrodusir Pilkada Serentak bertahap yang dimulai pada tahun 2015-2020 telah mengadopsi sistem penegakan hukum yang hampir seragam dalam pintu dan kelembagaannya, yakni beragamnya lembaga penegak hukum (LPH) Pilkada dan aparat penegak hukum (APH) Pilkada

Lembaga penegak hukum (LPH) Pilkada, yakni Badan Pengawas Pemilu (Bawaslu), Dewan Kehormatan Penyelenggara Pemilu (DKPP), Kepolisian, Kejaksaan, Pengadilan Negeri (PN), Pengadilan Tinggi (PT), Pengadilan Tata Usaha Negara (PTUN) yang bermuara ke Mahkamah Agung Republik Indonesia (MA RI) dan Mahkamah Konstitusi Republik Indonesia (MK RI). Sedangkan aparatur penegak hukum (APH) Pilkada, yakni Bawaslu, DKPP, Polisi, Jaksa dan
Hakim. Masing-masing LPH dan APH memiliki tugas, fungsi dan kewenangan yang berbeda-beda berdasarkan pilihan politik hukum pembuat UU Pilkada.

Pilihan politik hukum pembuat UU Pilkada mengadopsi model LPH dan APH Pilkada yang tidak tunggal. Akibatnya pintu-pintu untuk memperoleh keadilan dalam penyelenggaraan Pilkada disediakan sedemikian rupa, sehingga pencari keadilan (yustiabelen) atau setiap aktor yang berhubungan langsung dan tidak langsung dengan penyelenggaraan Pilkada, yakni penyelenggara, peserta Pilkada dan publik/setiap warga negara dapat memilih sesuai dengan masalah-masalah hukum Pilkada yang dihadapinya.

Di satu sisi beragamnya pintu memperoleh keadilan dalam Pilkada ini menunjukkan, karena begitu kompleknya masalah-masalah hukum dalam Pilkada menjadi motif utama agar disediakan pula beragam LPH Pilkada dan APH Pilkada semula mungkin ditujukan untuk mewujudkan keadilan Pilkada Namun, dalam prakteknya justru menjadi problem tersendiri dalam penegakan hukum Pilkada, karena masing-masing $\mathrm{LPH}$ dan APH Pilkada tidak memiliki kesamaan persepsi dalam menafsirkan norma UU Pilkada. Maka selain prosedur dan putusannya berbeda-beda. Bahkan berpotensi para pihak termotivasi untuk selalu melakukan uji coba peruntungan dari satu LPH ke LPH Pilkada yang lain Akibatnya tak berkepastian hukum sehingga 
berpotensi keadilan substantif tak terwujud.

Sebagai contoh, tingginya jumlah sengketa Pemilukada yang dibawa ke MK mengindikasikan bahwa tingkat kepercayaan dan legitimasi terhadap hasil pelaksanaan Pemilukada masih rendah. Terjadi peningkatan persentase sengketa pilkada yang dilaporkan ke MK pada 2015 dan 2017. Pada 2015, dari 264 daerah yang menggelar pilkada serentak, jumlah perkara sengketa pilkada yang diajukan ke MK sebanyak 152 perkara (57,5 persen). Sementara itu, pada 2017, dari 101 daerah yang menggelar pilkada serentak, jumlah perkara sengketa pilkada yang masuk ke MK sebanyak 60 perkara (59 persen). (Kompas, 2018). Sedangkan pada Pilkada tahun 2018 permohonan sengketa hasil Pilkada yang diajukan ke MK sebanyak 56 permohonan (Kompas, 2018).

Artinya, para peserta Pemilukada masihtidakpuas dengan penyelenggaraan Pemilukada baik dalam prosesnya maupun dalam hasil akhirnya. Banyak pelanggaran dan perselisihan dalam tahapan pemilu yang semestinya diajukan ke penegak hukum lain justru diajukan ke MK. Dalam beberapa permohonan perselisihan hasil Pemilukada, para peserta justru memasukkan pelanggaranpelanggaran administrasi, tindak pidana pemilu dan sengketa dalam tahapan pemilu sebagai dasar gugatan. Padahal, ketiga hal tersebut bukan kewenangan MK. Untuk tindak pidana pemilu (election offences) dapat diselesaikan melalui peradilan pidana seperti kepolisian, penuntut umum, dan pengadilan. Sedangkan, untuk pelanggaran administrasi dapat diselesaikan melalui Komisi Pemilihan Umum Daerah. Sementara, sengketa dalam proses atau tahapan pemilu diselesaikan melalui Badan Pengawas Pemilu atau Panitia Pengawas Pemilu (Zoelva, 2013, hlm. 392-393).

Artikel ini hendak mengkaji dan mendalami tentang implikasi pilihan model beragamnya pintu pencari keadilan dalam Pilkada ini berpotensitakterwujudnyakeadilan substansial dalam penyelenggaraan Pilkada dan mengusung gagasan model integrasi penegakan hukum Pilkada dengan cara merevitalisasi peran Bawaslu saat ini menjadi semi peradilan (quasi judiciary), yaitu Badan Penyelesaian Hukum Pemilihan (BPHP) atau semacan badan tunggal yang menyelesaiakan masalah pelanggaran hukum pilkada, berupa pelanggaran admnistrasi dan sengketa Pilkada yang putusannya bersifat final dan mengikat.

\section{Metode Penelitian}

Metode penelitian yang digunakan dalam penulisan ini adalah penelitian hukum normatif. Pendekatan yang digunakan dalam penelitian adalah asas hukum, perundangan, dan konseptual. Teknik pengumpulan data dilakukan denganmetodestudipustaka. Teknis analisis data dengan menggunakan metode hermeneutika, yakni 
mendeskripsikan secara objektif dan sistematis isi norma dan praktiknya secara interaktif.

\section{Perspektif Teori}

\section{a. Teori Keadilan Pemilu}

Esensi yang hendak dicapai dalam penegakan hukum pemilu adalah mewujudkan keadilan (fainess). Keadilan pemilu akan berwujud dalam suatu aturan atau kebijakan yang diterapkan menurut prinsip-prinsip keadilan sebagai fairness yang juga bersesuaian dengan prinsip keadilan sosial yang terkandung dalam sila kelima Pancasila. Maka keadilan pemilu dapat dirumuskan sebagai pelaksanaan pemilu yang tunduk pada aturan-aturan (termasuk pembatasan-pembatasan) hukum pemilu yang adil dan memberi ruang kebebasan dan kesetaraan antar warga negara dalam suatu sistem demokrasi yang menguntungkan semua warga negara. (Fahmi, 2016, hlm.183)

Keadilan pemilu juga sampai pada level bagaimana institusi penyelenggara pemilu diisi oleh orang-orang nonpartisan serta mampu bekerja dengan integritas yang terjaga. Bahkan, keadilan pemilu juga menjangkau titik yang paling rumit, di mana rakyat sebagai tumpuan demokrasi memiliki pemahaman yang cukup akan keberadaannya sebagai penentu proses peralihan kekuasaan melalui pemilu yang berjalan secara fair. Dengan demikian, keadilan pemilu mencakup semua aspek yang mempengaruhi bagaimana pemilu sebagai sebuah kontestasi berjalan secara bebas dan setara. (Fahmi,2016, hlm.184)

\section{Dalam perpektif hukum}

keadilan merupakan tema penting karena menempati posisi sentral tentang jawaban atas pertanyaan tujuan hukum. Itulah sebabnya dalam penegakan hukum yang melibatkan tiga aspek: hukum materil, hukum formil dan aparatur hukum, relasi erat ketiganya dapat dijelaskan sebagai berikut:

Pertama, hukum materil (materil legal subtance) yang mengatur tentang isi norma berupa: perintah, larangan dan sanksi. Kedua, hukum formil (formil legal subtance) yang mengatur mengenai hukum prosedural. Ketiga, struktur hukum (structure of law) yang mengatur tentang fungsi, tugas dan kewenangan aparatur penegak hukum.

Ketiganya tak bisa dipisahkan karena sangat erat hubunganya antara yang satu dengan yang lain. Oleh karena itu ketiganya merupakan suatu rangkaian mozaik yang mutualis-simbiosis. Hukum materil tak mungkin ditegakan tanpa menggunakan hukum prosedural, menjalankan hukum materil dan prosedural itu memerlukan peran aparat penegak hukum yang berintegritas.

Dalam penegakan hukum acapkali mengutamakan menjalankan hukum materil secara ketat apa adanya dengan menerapkanya melalui hukum prosedural oleh aparatur hukum. Penegakan hukum yang lebih menggutamakan bunyi norma 
peraturan tanpa penafsiran kontekstual disebut positivistik. Sedangkan penegakan hukum dengan menempatkan tujuan utama keadilan kendati harus memgesampingkan bunyi norma dan hukum prosedural oleh aparat hukum disebut sebagai penegakan hukum substansial.

$P$ e $n$ g e ja wa $n t a h$ a $n$ mengutamakan aspek substansial ini telah melahirkan sejumlah teori substansial dengan berbagai nama antara lain, hukum progresif dan hukum responsif. Hukum Progresif menjalankan hukum dengan tidak sekedar dengan logika melainkan dengan keperpihakan pada manusia karena memang hukum untuk manusia bukan manusia untuk hukum. (Rahardjo, 2012, hlm 9-10) dan (Rahardjo, 2008, hlm. ix$\mathrm{x})$.

Sedangkan Hukum responsif beranggapan bahwa tujuan dapat dibuat cukup objektif dan cukup berkuasa untuk mengontrol pembuatan peraturan yang adaptif. (Nonet \& Selznick, 2003, hlm. 62). Bagi tatanan hukum responsif, hukum merupakan institusi sosial. Oleh karena itu, hukum dilihat lebih dari sekedar suatu sistem peraturan belaka, melainkan juga bagaimana hukum menjalankan fungsi-fungsi sosial dalam dan untuk masyarakatnya.

\section{b. Teori Pilkada Serentak}

Pilkada Serentak di Indonesia tidak benar-benar serentak sebagaimana dalam teori pemilu serentak, yakni dilaksanakan secara nasional pada waktu yang sama, baik, tanggal, bulan dan hari yang sama.

Bahkan serentak ini berbeda pula dalam praktek yang lazim dilakukan oleh banyak negara demokrasi yang stabil. Adapun yang dimaksud serentak dalam tradisi pemilu serentak seharusnya adalah melaksanakan pemilu nasional untuk memilih presiden dan anggota legislatif waktunya bersamaan dan pelaksanaan pemilu lokal untuk memilih kepala daerah dan pemilu parlemen untuk memilih anggota DPRD pada waktu yang bersamaan (concurrent) (Samuels, 2000, hlm. 1-20).

Kepentingan jangka panjang yang hendak dituju dari pilihan politik hukum sistem Pilkada Serentak adalah:

Pertama, untuk efisiensi dan efektifitas Anggaran, dengan model serentak akan dapat menghemat biaya yang akan dikeluarkan dalam Pilkada. Kedua, menghemat waktu dan tenaga penyelenggara. Ketiga, menghilangkan kejenuhan pemilih. Keempat, meningkatkan kontrol publik. Kelima, menghasilkan pemerintahan daerah dan pusat yang sama (concruent).

Keenam, menghadirkan Coattail Effect, (Golder, 2006, hlm. 34-38), yaitu Tindakan Politik yang menimbulkan pengaruh kepada tindakan lain (Pengaruh ikutan). Hal ini terkait dengan faktor psikologi pemilih dalam menentukan pilihan dalam pemilu, dimana pemilih memiliki kecenderungan bagi seorang pemimpin parpol populer yang dicalonkan untuk jabatan ekeskutif (presiden, gubernur, 
walikota, bupati) menimbulkan daya tarik pemilih kepada calon lain dari parpol yg sama dalam pemilihan umum. Sebagai contoh, calon presiden (Capres) A akan mempengaruhi keterpilihan calon legislatif (Caleg) dari parpol/koalisi yg mengajukan Capres A.

Pilkada Serentak juga akan dapat mengurangi kesibukan partai politik dalam megangani konflik internal dan mendorong parpol menjalin hubungan dengan konstituen, memperbanyak kesempatan kader-kader parpol berkompetisi, membentuk pemerintah konstruktif dan menciptakan agenda politik lima tahun yang jelas (Zuhro, 2015, hlm. 367).

\section{c. Teori Penegakan Hukum Pilkada}

Dari aspek etimologi istilah penegakan hukum diambil dari bahasa Belanda rechtstoepassing atau rechtshandhaving dan bahasa Inggris law enforcement. Adapun pengertian mengandung 2 (dua) sifat makro dan mikro. Sifat makro adalah suatu upaya dalam mewujudkan ditaatinya hukum dan peraturan perunndangundangan oleh seluruh masyarakat dalam kehidupan berbangsa dan bernegara, sedangkan sifat mikro yakni usaha untuk menjadikan hukum dan peraturan perundangundangan dalam proses penegakan hukum dari di pengadilan mulai dari proses penyelidikan, penyidikan, penuntutan hingga pelaksanaan putusan yang mempunyai kekuatan hukum tetap (Chaerudin, dkk.,
2008, hlm. 87).

Menurut Soerjono Soekanto, pada hakikatnya inti penegakan hukum terletak pada kegiatan menyerasikan hubungan nilainilai yang terjabarkan di dalam kaidah-kaidah yang mantap dan mengejawantah dan sikap tindak sebagai rangkaian penjabaran tahap akhir, untuk menciptakan, memelihara dan mempertahankan kedamaian pergaulan hidup. (Soekanto, 2004, hlm. 42).

Terdapat sejumlah persyaratan yang menjadi dasar bagi pembangunan sistem penegakan hukum pemilu yang baik. Persyaratan itu adalah: i) adanya mekanisme dan penyelesaian hukum yang efektif, ii) adanya aturan mengenai sanksi yang jelas atas pelanggaran pemilu, iii) adanya ketentuan terperinci dan memadai untuk melindungi hak pilih, iv) adanya hak bagi pemilih, kandidat, partai politik untuk mengadu kepada lembaga penyelenggara pemilu atau lembaga pengadilan, v) adanya kewenangan untuk mencegah hilangnya hak pilih yang diputuskan olehlembaga penyelenggara pemilu atau lembaga pengadilan, vi) adanya hak untuk banding, adanya keputusan yang sesegera mungkin, vii) adanya aturan main mengenai waktu yang dibutuhkan untuk memutuskan gugatan, viii) adanya kejelasan mengenai implikasi bagi pelanggaran aturan pemilu terhadap hasil pemilu, dan ix) adanya proses, prosedur, dan penuntutan yang menghargai hak asasi manusia. (Santoso, dkk, 2006, 
hlm. 101-102).

Tujuan untama penegakan hukum pemilu adalah untuk memastikan bahwa semua tahapan dan proses pemilu dapat berlangsung sesuai perencanaan dan ditaatinya peraturan yang mengaturnya sehingga tercipta ketertiban dalam semua proses pemilu (electoral process order), serta sanksi hukumannya dapat melahirkan efek penjeraan (deterence effect) bagi pelanggarnya dan tak terulang dikemudian hari (Ellis, 2003, hlm. 337-351).

Selain itu tujuan penegakan hukum pemilu juga seperti dinyatakan oleh Gutav Radbruch, yaitu kepastian hukum (Rechtssicherheit), kemanfaatan (Zweckmassigkeit) dan keadilan (Gerechtigkeit) (Manullang, 2016, hlm. 127).

Sistem penegakan hukum menggunakan dua modelkekuasaan peradilan ini umumnya dianut oleh negara di Eropa, seperti, Jerman, Perancis dan Rusia sebagai negara yang mengalami transisi demokrasi (Nusantara: 2019, hlm.1).

\section{Hasil dan Pembahasan}

a. Multi Pintu Lembaga dan Aparat Hukum Pilkada

Dalam penegakan hukum Pilkada terdapat berbagai pilihan alternatif (many rooms to justice). Lembaga penegak hukum Pilkda (LPH) beragam, yakni Badan Pengawas Pemilu (Bawaslu), Dewan Kehormatan Penyelenggara Pemilu (DKPP), Kepolisian Republik
Indonesia (Polri), Kejaksaan Negeri (Kejari) dan Pengadilan Negeri, Pengadilan Tinggi dan Pengadilan Tata Usaha Negara bermuara di Mahkamah Agung RI (MA RI). Aparat penegak hukum Pilkada $(\mathrm{APH})$ juga beragam, yakni, Bawaslu, DKPP, Polisi, Jaksa, Hakim. Adapun

lembaga pengadilan yang digunakan untuk menyelesaikan sengketa proses dan tahapan Pilkada dan penyelesaian perselisihan hasil Pilkada juga beragam, yakni di 2 (dua) lembaga kekuasaan kehakiman yang berbeda dan terpisah, yakni Mahkamah Agung (MA) memegang kekuasaan kehakiman (ordinary court) menyelesaikan sengketa proses dan tahapan Pilkada dan pidana Pilkada dan Mahkamah Konstitusi (MK) memegang kekuasaan kehakiman dalam perkara ketatanegaraan (constitutional court) yang berwenang menyelesaikan perselisihan hasil Pilkada.

Pelaksanaan Pilkada di Indonesia berdasarkan ketentuan Pasal 135 ayat (1) UU 1 Tahun 2015 jo. UU 8 Tahun 2015 jo. UU 10 Tahun 2016 tentang Pemilihan Gubernur, Bupati dan Walikota (UU Pilkada) telah mengadopsi 4 (empat) model masalah hukum Pilkada dimana masing-masing model tersebut diatur hukum materil (legal substance), hukum formil (legal prosedure) dan kelembagaan yang melakukan penegakan hukum pilkada (legal structure) yang berbeda-beda (justice in many rooms). 
b. Hukum Materil Pilkada

Pilkada yang berlangsung sejak tahun 2005 hingga tahun 2020 diperkenalkan hukum materi (legal substance) yang mengatur tentang kategori perbedaan pelanggaran. Paling tidak terdapat 5 (lima) norma pelanggaran hukum Pilkada, yaitu:

Pertama,

Pelanggaran

administrasi Pilkada, yaitu pelanggaran yang meliputi tata cara, prosedur, dan mekanisme yang berkaitan dengan administrasi pelaksanaan Pemilihan dalam setiap tahapan penyelenggaraan Pemilihan di luar tindak pidana pemilihan dan pelanggaran kode etik penyelenggara Pemilihan. (Pasal 138 Ayat 1 UU No.10/2016). Namun dalam perkembangan terdapat kualifikasi baru yang semula termasuk tindak pidana diubah menjadi pelanggaran admnistrasi pemilihan, yakni pemberian uang (money politic) yang dilakukan calon jika dilakukan secara terstruktur, sistematis dan masif (TSM) dapat dijatuhi sanksi admnistrasi pembatalan sebagai calon.

Kedua, sengketa pemilihan, yaitu sengketa Pemilihan terdiri atas: (a). sengketa antarpeserta Pemilihan; dan (b). sengketa antara Peserta Pemilihan dan penyelenggara Pemilihan sebagai akibat dikeluarkannya Keputusan KPU Provinsi dan KPU Kabupaten/ Kota. (Pasal 142 UU Pilkada).

Ketiga,tindak pidana pemilihan,merupakan pelanggaran atau kejahatan terhadap ketentuan pemilihan sebagaimana diatur dalam UU Pilkada. Bentuk tindak pidana pemilihan misalnya, memberikan keterangan yang tidak benar mengenai diri sendiri atau diri orang lain tentang suatu hal yang diperlukan untuk pengisian daftar pemilih, melakukan kampanye diluar jadwal yang telah ditetapkan, melakukan intimidasi dan kekerasan terhadap para pemilih, menjanjikan dan/atau memberikan uang atau materi lainnya untuk mempengaruhi pemilih.

Keempat, pelanggaran kode etik penyelenggara pemilihan, pelanggaran terhadap etika penyelenggara pemilihan yang berpedoman pada sumpah dan/ atau janji sebelum menjalankan tugas sebagai penyelenggara pemilihan. Subyek pelanggarnya adalah para penyelenggara pemilu/ pilkada baik di tingkat pusat hingga tingkat tempat pemungutan suara (TPS).

Kelima, perselisihan hasil Pilkada, yaitu Perselisihan hasil Pemilihan adalah perselisihan antara KPU Provinsi dan/atau KPU Kabupaten/Kota dan peserta Pemilihan mengenai penetapan perolehan suara hasil Pemilihan. Perselisihan penetapan perolehan suara hasil Pemilihan adalah perselisihan penetapan perolehan suara yang signifikan dan dapat mempengaruhi penetapan calon untuk maju ke putaran berikutnya atau penetapan calon terpilih diajukan ke MK RI. (Pasal 156 Ayat 1 dan 2 UU Pilkada). 
Dapat digambarkan dalam ragaan berikut ini:

\begin{tabular}{|c|l|}
\hline No & \multicolumn{1}{|c|}{$\begin{array}{c}\text { Model Hukum Materil } \\
\text { Pilkada }\end{array}$} \\
\hline 1 & $\begin{array}{l}\text { Pelanggaran Administrasi } \\
\text { Pilkada }\end{array}$ \\
\hline 2 & Sengketa Pemilihan \\
\hline 3 & Tindak Pidana Pilkada \\
\hline 4 & $\begin{array}{l}\text { Pelanggaran Kode etik } \\
\text { Penyelenggara Pemilihan }\end{array}$ \\
\hline
\end{tabular}

\section{c. Hukum Formil Pilkada}

Masing-masing jenis pelanggaran tersebut diatur model prosedur penanganan yang berbeda di dalam UU Pilkada.

Pertama, terkait dengan pelanggaran admnistrasi pemilihan yang menyangkut tentang tata cara yang berkaitan dengan pelaksanaan Pilkada diatur prosedurnya penegakan hukumnya dapat dimulai dari hasil temuan oleh Bawaslu Propinsi/Kabupaten/Kota/ Panwas Kecamatan/PPL dan Pengawas TPS dan atau berasal dari laporan adanya dugaan pelanggaran. Adapun yang dapat melaporkan dugaan pelanggaran adalah pemilih, pemantau pemilihan dan peserta pemilihan, yang disampaikan secara tertulis yang memuat paling sedikit nama dan alamat pelapor, pihak pelapor, waktu dan tempat kejadian perkara dan uraian kejadian. Laporan tersebut diatur limitasinya paling lama 7 (hari) sejak diketahui dan atau ditemukan pelanggaran. Bawaslu Propinsi hingga Pengawas TPS wajib menindaklanjuti laporan paling lama 3 (tiga) hari setelah laporan diterima.

Kedua, terkait dengan sengketa pemilihan, yaitu sengketa Pemilihan antarpeserta Pemilihan; dan sengketa antara Peserta Pemilihan dan penyelenggara Pemilihan sebagai akibat dikeluarkannya Keputusan KPU Provinsi dan KPU Kabupaten/Kota. Diatur hukum formilnya sama dengan pelanggaran hukum admnistrasi hanya saja Bawaslu Propinsi dan Bawaslu Kabupaten/Kota diberi wewenang untuk memutuskan sengketa antar peserta Pilkada dengan cara menerima dan mengkaji laporan atau temuan, kemudian mempertemukan pihak yang bersengketa untuk mencapai kesepakatan melalui musyawarah dan mufakat. Jika para pihak tidak menerima putusan Bawaslu dapat melakukan gugatan ke PTTUN dan dapat melakukan kasasi ke Mahkamah Agung RI.

Ketiga, tindak pidana pemilihan merupakan pelanggaran atau kejahatan terhadap ketentuan pemilihan sebagaimana diatur dalam UU Pilkada. Dapat pelapor dapat melaporkan kepada Bawaslu Propinsi dan Bawaslu Kab/ Kota. Laporan tersebut dibawa dalam forum Setra Penegakan Hukum (Gakumdu) untuk menyamakan pemahaman dan pola penanganan tindak pidana Pemilihan. Anggota Gakumdu terdiri dari: Bawaslu Provinsi, 
dan/atau Panwas Kabupaten/ Kota, Kepolisian Daerah dan/atau Kepolisian Resor, dan Kejaksaan Tinggi dan/atau Kejaksaan Negeri. Jika terpenuhi unsur pidana penyidik Polri menyampaikan berkas penyidikan ke penuntut umum (Jaksa). Penuntut umum melanjutkan ke Pengadilan Negeri (PN). Para pihak dapat melakukan banding ke Pengadilan Tinggi (PT) putusan PT bersifat final dan mengikat.

Keempat, terkait dengan pelanggaran kode etik penyelenggara pemilihan, diatur prosedur dan waktunya sebagaimana penanganan pelanggaran admnistrasi dan pelanggaran sengketa pemilihan Bawaslu dapat meneruskan ke Dewan Kehormatan Penyelenggara Pemilu (DKPP) jika yang melakukan pelanggaran adalah KPU dan jajarannya, atau pelapor dapat melaporkan langsung ke DKPP jika yang melakukan pelangaran adalah Bawaslu dan jajarannya.

\section{d. Aparat Penegak Hukum Pilkada}

Dalam penegakan hukum Pilkada diperkenalkan sejumlah lembaga yang diberi wewenang untuk menyelesaikan permasalah pelanggaran hukum Pilkada. Aparat penegak hukum (APH) Pilkada yaitu:

Pertama, Bawaslu RI yang memiliki kewenanagan Menerima, memeriksa, dan memutus keberatan atas putusan Bawaslu Provinsi terkait pemilihan diskualifikasi. Menindaklanjuti rekomendasi dan/ atau putusan Bawaslu Provinsi maupun Panwas Kabupaten/Kota kepada KPU terkait terganggunya tahapan Pemilihan.

Kedua, Bawaslu Propinsi dan kabupaten/Kota yang memiliki wewenang untuk menyelesaikan pelanggaran tata cara, prosedur, dan mekanisme berkaitan dengan tahapan Pilkada.

Ketiga, Sentra Penegakan Hukum Terpadu (Sentra Gakumdu) yang keanggotaanya terdiri darai Bawaslu, Kepolisian dan Kejaksaan yang memiliki wewenang dalam menyamakan pemahaman ola penanganan tindak pidana Pilkada.

Keempat, Kepolisian yang diberi wewenang untuk melakukan penyidikan dan melimpahkan penyidkan ke penuntut umum dalam perkara pidana Pilkada,

Kelima, Kejaksaan yang diberi wewenang untuk melimpahkan berkas perkara perkara pidana hasil penyidikan Polri dan setelah dilakukan dakwaan dan tuntutan untuk disampaikan ke pengadilan negeri (PN).

Keenam, Pengadilan Negeri yang diberi wewenang untuk melakukan pemeriksaan, mengadili, dan memutus perkara tindak pidana Pilkada.

Ketujuh, Pengadilan Tinggi (PT) yang diberi wewenang untuk memeriksa dan memutus perkara banding pidana Pilkada yang putusannya bersifat terakhir dan mengikat.

Kedelapan, Pengadilan Tinggi Tata Usaha Negara (PTTUN) yang berwenang untuk menyelesaikan sengketa antar peserta pemilihan, 


sengketa antar peserta
pemilihan dengan penyelenggara
pemilihan sebagai akibat
dikeluarkannya keputusan KPU.
Kesembilan, Mahkamah Agung
RI yang diberi wewenang untuk
memutus upaya hukum pelangaran
admnistrasi pembatalan calon
karena politik uang dan Memberikan
putusan atas permohonan kasasi
sengketa Pilkada yang bersifat final.
Kesepuluh, Mahkamah
Konstitusi RI yang berwenang
dalam memeriksa dan mengadili
perselisihan hasil pilkada sampai di
bentuknya peradilan khusus.
Kesebelas, DKPPyang berwenang
dalam menangani pelanggaran kode
etik penyelenggara Pemilu.
Kewenangannya akan
diuraikan dalam bagan berikut ini:




\begin{tabular}{|c|c|c|c|}
\hline No. & $\begin{array}{l}\text { PILIHAN } \\
\text { LEMBAGA }\end{array}$ & DASAR HUKUM & KEWENANGAN \\
\hline 1. & Bawaslu RI & $\begin{array}{l}\text { Pasal 22B huruf } \\
\text { b dan huruf jo } \\
\text { UU No.10/2010 }\end{array}$ & $\begin{array}{l}\text { 1. Menerima, memeriksa, dan memutus } \\
\text { keberatan atas putusan Bawaslu Provinsi } \\
\text { terkait pemilihan diskualifikasi. } \\
\text { 2. menindaklanjuti rekomendasi dan/atau } \\
\text { putusan Bawaslu Provinsi maupun Panwas } \\
\text { Kabupaten/Kota kepada KPU terkait } \\
\text { terganggunya tahapan Pemilihan }\end{array}$ \\
\hline 2. & $\begin{array}{l}\text { B a w a s I u } \\
\text { Propinsi/Kab/ } \\
\text { Kota }\end{array}$ & $\begin{array}{l}\text { Pasal } 138 \text { Ayat } \\
\text { (1), (2) dan (3) } \\
\text { UU No.1/2015 }\end{array}$ & $\begin{array}{l}\text { Menyelesaikan pelanggaran tata cara, prosedur, } \\
\text { dan mekanisme berkaitan dengan tahapan } \\
\text { Pilkada }\end{array}$ \\
\hline 3. & $\begin{array}{l}\mathrm{S} \text { e } \mathrm{n} \text { t } r \text { a } \\
\text { Gakumdu dan } \\
\text { PN }\end{array}$ & $\begin{array}{lr}\text { Pasal } & 152 \\
\text { Ayat (1) UU } \\
\text { No.10/2016 }\end{array}$ & $\begin{array}{l}\text { Menyamakan pemahaman ola penanganan } \\
\text { tindak pidana Pilkada }\end{array}$ \\
\hline 4. & Kepolisian & $\begin{array}{l}\text { Pasal } 146 \text { Ayat } \\
\text { (1), (2) dan (3) } \\
\text { UU No.10/2016 }\end{array}$ & $\begin{array}{l}\text { Penyidikan dan Melimpahkan penyidkan ke } \\
\text { penuntut umum }\end{array}$ \\
\hline 5. & Kejaksaan & $\begin{array}{lr}\text { Pasal } & 146 \\
\text { ayat } \quad(4) & \text { UU } \\
\text { No.10/2016 }\end{array}$ & Melimpahkan berkas perkara ke PN \\
\hline 6. & PN & $\begin{array}{l}\text { Pasal } 147 \text { Ayat } \\
\text { (1) dan (2) UU } \\
\text { No.10/2016 }\end{array}$ & $\begin{array}{l}\text { Memeriksa, mengadili, dan memutus perkara } \\
\text { tindak pidana Pilkada }\end{array}$ \\
\hline 7. & PT & $\begin{array}{l}\text { Pasal } 148 \text { Ayat } \\
\text { (4) dan (5) }\end{array}$ & $\begin{array}{l}\text { Memeriksa dan memutus perkara banding } \\
\text { pidana Pilkada terakhir dan mengikat }\end{array}$ \\
\hline 8. & PTTUN & $\begin{array}{l}\text { Pasal } 153 \text { Ayat } \\
\text { (1) dan Pasal } \\
154 \text { Ayat (1) UU } \\
\text { No.10/2016 }\end{array}$ & $\begin{array}{l}\text { Menyelesaikan sengketa antar peserta } \\
\text { pemilihan, sengketa antar peserta pemilihan } \\
\text { dengan penyelenggara pemilihan sebagai akibat } \\
\text { dikeluarkannya keputusan KPU }\end{array}$ \\
\hline 9. & MA RI & $\begin{array}{l}\text { Pasal } 135 \mathrm{~A} \text { ayat } \\
\begin{array}{ll}\text { (7) dan Pasal } \\
154 \text { Ayat } & (9) \\
\text { dan (10) UU } & \text { No.10/2016 }\end{array}\end{array}$ & $\begin{array}{l}\text { 1. Memutus upaya hukum pelangaran } \\
\text { admnistrasi pembatalan calon karena politik } \\
\text { uang } \\
\text { 2. Memberikan putusan atas permohonan } \\
\text { kasasi sengketa KTUN KPU bersifat final }\end{array}$ \\
\hline 10. & MK RI & $\begin{array}{lr}\text { Pasal } & 157 \\
\text { Ayat } \quad \text { (3) UU } \\
\text { No.10/2016 }\end{array}$ & $\begin{array}{l}\text { Memeriksa dan mengadili perselisihan hasil } \\
\text { pilkada sampai di bentuknya peradilan khusus }\end{array}$ \\
\hline 11. & DKPP & $\begin{array}{lrr}\text { Pasal } & 137 & \text { Ayat } \\
\text { (1) dan } & (2) \\
\text { angka } 24 & \text { UU } \\
\text { No.1/2015 } & \end{array}$ & $\begin{array}{l}\text { Menangani pelanggaran kode etik penyelenggara } \\
\text { Pemilu }\end{array}$ \\
\hline
\end{tabular}


e. Implikasi Keragaman Pintu Keadilan Pilkada Perspektif Kepastian

Terkait dengan keragaman dalam hal kualifikasi subtansi peraturanpelanggaran Pilkada (legal substance), keragaman prosedur penanganan dalam penegakan hukum Pilkada (legal prosdure) dan keragaman lembaga penegakannya (legal structure) yang diberi wewenang untuk menegakkan hukum Pilkada diuraikan di atas menunjukkan, bahwa penegakan hukum Pilkada sangat rumit, birokratik dan dapat berakibat pada ketidakpastian hukum bagi pencari keadilan (yustiabelen).

Di satu sisi beragamnya pintu memperoleh keadian dalam Pilkada ini menunjukkan, karena begitu kompleknya masalahmasalah hukum dalam Pilkada menjadi motif utama mengapa pembuat UU Pilkada menyediakan aneka pintu yang beragam (justice in many rooms) baik dari aspek lembaga penegak hukum (LPH) Pilkada dan aparat penegak hukum (APH) Pilkada agar mewujudkan keadilan Pilkada tercapai. Namun di sisi lain beragamnya LPH dan APH Pilkada ini dalam prakteknya justru menjadi problem tersendiri dalam penegakan hukum Pilkada, karena masing-masing $\mathrm{LPH}$ dan $\mathrm{APH}$ Pilkada tidak memiliki kesamaan persepsi dalam menafsirkan norma UU Pilkada. Akibatnya selain prosedur dan putusannya berbedabeda juga berpotensi para pihak termotivasi untuk selalu melakukan uji coba peruntungan dari satu LPH ke LPH Pilkada yang lain.

Dari perpektif maksud dan tujuan penegakan hukum Pilkada melalui beragamnya pintu keadilan ini menunjukkan tidak jelas philosofis tujuannya: (i) apakah untuk melindungi hak peserta Pilkada; (ii) apakah untuk melindungi hak penyelenggara Pilkada; (iii) apakah untuk melindungi hak pemilih; atau (iv) apakah ditujukan untuk menegakkan ketertiban hukum masyarakat secara umum.

Dalam penegakan hukum Pilkada dengan beragamnya pintu mencari keadilan itu tak mungkin dapat terwujud keempat tujuan itu. Maka idealnya penegakan hukum pilkada harus terlebih dahulu ditentukan tujuan filosofisnya agar dapat diukur dipastikan apa yang hendak diutamakan dalam mencapai dan mewujudkan perlindungan hak-hak tersebut.

\section{f. Implikasi Keragaman Pintu Keadilan Pilkada Perspektif Ekonomi}

Dalam kajian teori hukum modern, sistem hukum dan putusan pengadilan bukan saja harus adil kepada siapa pun (equality before the (aw), namun juga harus memerhatikan aspek analisis ekonomi, berupa efektivitas dan efisiensi dalam penegakan hukum.

Hal ini seperti dinyatakan oleh Richard A. Posner (1999) dalam bukunya Economic Analysis of Law, yang antara lain menyatakan dalam membuat putusan hukum yang adil selain pertimbangan kemanusiaan juga aspek ekonomi. 
Sistem hukum Pilkada harus dibangun berdasarkan asas-asas ekonomi, terutama aspek untung dan rugi. Negara harus menghitung secara matematika ekonomi, apakah sepadan antara kerugian yang ditimbulkan akibat suatu pelanggaran hukum Pilkada dengan biaya yang dikeluarkan oleh negara dalam memproses hukum kasuskasus Pilkada.

Jika teori ini digunakan untuk menganalis tentang beragamnya pintu keadilan Pilkada, seharus sejak proses di Bawaslu, DKPP, penyidikan di kepolisian, di kejaksaan, dan hingga proyustisia di pengadilan (PN/PT/PTTUN) harus terlebih dahulu mengkaji dan mencermati apakah pelanggaran hukum Pilkada itu sebanding dengan biaya (uang/ anggaran) yang dikeluarkan negara untuk membiayai Bawaslu, DKPP, Polisi, Jaksa, dan Hakim dalam memproses hukum kasus ini.

Jika didapat hasil biaya negara lebih mahal daripada kerugian dari pelanggaran hukum Pilkada, maka seharusnya keberagaman ini perlu dievaluasi kembali. Dapat dipastikan prosedur yang panjang dan LPH dan APH Pilkada yang beragam menimbulkan biaya ekonomi yang mahal.

\section{g. Implikasi Keragaman Pintu Keadilan Pilkada Perspektif Keadilan Pemilu}

Pendekatan hukum dan ekonomi ini telah menjadi tren baru dalam penegakan hukum di negaranegara yang menganut paham hukum Aglosaxon atau model Amerika di benua Amerika, Afrika, maupun Asia.
Hal ini dilakukan terutama untuk menemukan keadilan substansial dan dapat mengalahkan keadilan prosedural.

Maka sebaiknya tidak semua kasus hukum Pilkada diproses di pengadilan. Hanya kasus-kasus hukum yang berat yang memiliki implikasi sosial politik luas di mata publik saja yang diproses di pengadilan. Kasus-kasus pelanggaran Pilkada yang kecil dan tak menimbulkan implikasi sosial yang luas tak perlu diproses di pengadilan.

Ini juga dimaksudkan untuk menghindari diskrepansi sistem hukum Pilkada, yakni aparat penegak hukum (APH) Pilkada biasanya hanya tunduk kepada prosedur hukum yang kaku dan terhadap apa yang dikehendaki oleh teks dalam undang-undang tanpa kreasi untuk mempertimbangkan aspek kemanusiaan dan keekonomian (efektif dan efisiensi).

Itulah sebabnya di negaranegara Aglosaxon aparat hukum diberi ruang yang bebas untuk menerjemahkan makna teks undangundang disertai dengan aspek moralitas dan independensi yang tinggi. Ini membuat pengadilan di sana relatif tak terjamah aspek suap dan jual beli putusan.

Lebih dari itu, dari perspektif keadilan substanti pratik penegakan hukum Pilkada selama ini terutama dalam upaya hukum seringkali tidak dapat memenuhi rasa keadilan masyarakat, misalnya putusan pengadilan yang baru diputus pasca tahapan Pilkada telah selesai dilaksanakan dan berlapis-lapisnya upaya hukum Pilkada sehingga 
kontra-produktif dengan tahapan Pilkada yang dibatasi oleh jangka waktu. Terlebih upaya hukum tersebut terpisah dalam beberapa lingkungan peradilan. Dengan kondisi tersebut, upaya hukum terhadap tahapan Pilkada menghadapi tantangan lebih lanjut dengan pelaksanaan Pilkada serentak karena tahapan proses pemilihan dan upaya hukum atas setiap tahapan pemilihan tersebut akan dilaksanakan secara bersamaan, sehingga bila menggunakan mekanisme peradilan sebagaimana hukum positif saat ini tentu mewujudkan Pilkada yang berkeadilan akan sulit untuk terwujud. (Siregar, 2020, hlm.316).

\section{h. Perlunya Integrasi Sistem Penegakan Hukum Pemilu di Bawaslu}

Guna menciptakan model sistem Pilkada Serentak yang demokratis dan adil dan efektif maka perlu dilakukan pembaruan model penegakan hukum pelanggaran adminstrasi, dan sengketa Pilkada dalam satu sistem penegakan hukum Pilkada yang terpadu dan terintegrasi. Sehingga tidak melahirkan model penyelesaian pelanggaran Pilkada yang tak efektif dan membawa efek jera bagi pelakunya dan dapat menurunkan derajat demokrasi.

Perlunya mengintegrasikan peradilan sengketa pemilu dalam satu atap (one roof system) di bawah koordinasi Badan Pengawas Pemilu (Bawaslu) untuk dapat menyelesaikan secara final dan mengikat semua jenis pelanggaran pemilu baik administrasi maupun sengketa pemilihan dan kode etik penyelenggara pemilu. Model ini akan mempercepat dan mengefektifkan jalannya proses peradilan khusus Pilkada dengan menetapkan hukum acara dan aparatnya secara khusus.

Cara demikian

perlu diperkuat dalam rangka untuk mewujudkan : (1) Kemandirian dan ketidakberpihakan; (2) Efisiensi; (3) Profesionalisme; (4) Penangan yang cepat terhadap pertikaian yang ada; (5) Stabil; dan (6) Transparansi. (IDEA, 2000).

Integrasi penegakan hukum Pilkada melalui revitalisasi Bawaslu sebagai lembaga semi peradilan (quasi judiciary). Nama ini dipilih sebagai alternatif untuk menghindari nama "Pengadilan" karena akan berkonsekuensi hukum ketatanegaraan yang rumit, terutama perlunya mengamademen Pasal 24 UUD 1945 yang mengatur tentang kekuasaan peradilan di Indonesia terdiri dari dua Mahkamah Agung dan Mahkamah Konstitusi.

Lebihdariitu,jikamenggunakan frase Peradilan khusus Pilkada akan membawa konsekuensi pada ketaatan asas sistem peradilan dimana aparaturnya harus berstatus jabatan "hakim" dengan mematuhi aneka prosedur rekrutmennya dan tunduk padak UU No.48 Tahun 2009 tentang Kekuasaan Kehakiman.

$$
\text { Maka pengintegrasian }
$$

Bawaslu sebagai quasi judiciari dapat dilakukan dengan cara berdiri sendiri tanpa terkait dengan Pasal 24 UUD 1945 dan UU No.48 Tahun 2009 tentang Kekuasaan 
Kehakiman serta MA RI dan MK RI. Maka pilihan yang tersedia adalah cukup langsung dirumuskannya ke dalam ketentuan UU Pilkada yang perlunya mengintegrasikan kewenangannya saat dalam hal penyelesaian hukum Pilkada terkait pelanggaran administrasi, sengketa pemilihan dan pelanggaran kode etik penyelenggara Pilkada.

$$
\text { Untuk keperluan }
$$

itu merevitalisasi fungsi Bawaslu yang ada saat ini sebagai semi peradilan yang terintegrasi (integration of quasi judiciary) di tingkat daerah Bawaslu Propinsi/Kabupaten/Kota. Guna menghindari penyalahgunaan wewenang dan kontrol maka perlu diatu agar putusan Bawaslu daerah putusannyadapatdilakukanbanding di Bawaslu RI. Adapun keanggotaan Bawaslu RI dan Bawaslu daerah dapat menggunakan pendekatan kombinasi antara profesional (Hakim dan Akademisi Hukum) dan non partisan (dari masyarakat sipil), profesional melalui seleksi yang ketat.

Pilihan

mengintegrasikan

penegakan hukum di Bawaslu ini maka Bawaslu didesain lebih berorientasi pada penegakan hukum dengan sanksi administrasi bukan pidana (Haris, 2019, hlm. 161).

Konsekuensi lain dari
pengintegrasian ini maka perlu
menghilangkan peran DKPP
dan dikurangi kewenangannya
dalam soal pengawasan tapi ke
penindakan. Sedangkan fungsi
pengawasan pemilu diserahkan
pada partisipasi publik dan
pemantau pemilu. (Riwanto, 2020,

hlm. 285).

Maka ke depan Bawaslu sandaran kehadiran yuridis Bawaslu tetaplah pada ketentuan Pasal 22E ayat (5) UUD 1945 sebagai penyelenggara Pemilu yang diberi kewenangan sebagai lembaga penyelesaian sengketa proses pemilihan yang bersifat semi peradilan (quasi judiciary) bukan lagi sebagai Badan Pengawas Pemilihan. Bawaslu yang ada saat ini akan direvitalisasi fungsinya sebagai Badan Penyelesaian Hukum Pemilihan (BPHP).

Lebih dari itu, maka perlu menghapuskan fungsi Bawaslu untuk memberikan rekomendasi kepada KPU, namun putusannya bersifat mengikat dan final saat dibacakan. Untuk memperkuat Bawaslu diperlukan penguatan Bawaslu dengan memberikan kewenangan hak panggil paksa kepada setiap pelanggar administrasi, sengketa pemilihan, dan kode etik pemilu.

Sedangkan terhadap pelanggaran tindak pidana Pilkada dapat langsung diproses oleh sistem peradilan pidana yang saat ini ada, yakni melalui pintu penyidikan di kepolisian, penuntut umum (jaksa), dan hakim di pengadilan secara bertingkat.

Sedangkan

perselisihan hasil Pilkada diselesaikan melalui Mahkamah Agung sesuai ketentuan Pasal 24 UUD 1945 dan Pasal 157 Ayat (1) Undang-Undang Nomor 10 Tahun 2016 Tentang Pemilihan Gubernur, Bupati dan Walikota. 


\section{Simpulan}

Berdasarkan uraian di atas dapat disimpulkan sebagai berikut:

1. Dalam penyelenggaraan Pilkada secara langsung sejak tahun 2005 hingga Pilkada serentak yang dimulai tahun 2015-2020 ini mengakomodasi 5 (lima) model kualifikasi hukum materil (legal subtance) pelanggaran, yakni: pelanggaran administrasi Pilkada, sengketa Pilkada, pidana Pilkada, kode etik penyelenggara Pilkada dan perselisihan hasil Pilkada. Pengaturan mengenai hukum prosedur/formil (legal prosedure) yang berbeda-beda dan pengaturan lembaga penegak hukum (LPH) Pilkada juga berbeda-beda antara lain, Bawaslu RI, Bawaslu Propinsi/Kabupaten/ Kota, DKPP, Kepolisian, Kejaksaan, PN, PT, PTTUN, MA, dan MK. Sedangkan aparat penegak hukum (APH) Pilkada juga beragam, yakni Bawaslu, DKPP, Polisi, Jaksa, dan Hakim.

2. Konsekuensi dari beragamnya pintu keadilan (justice in many rooms) Pilkada ini berimplikasi pada tak terwujudnya keadilan keadilan pemilu, namun lebih menitikberatkan pada prosedural yang panjang dan bertingkat. Membuat para pencari keadilan mencoba mencari peruntungan di $\mathrm{LPH}$ dan APH yang lain dalam kasus Pilkada. Tak efektif dari aspek hukum ekonomi dan tak jelas filosofi tujuan penegakan hukum Pilkada.

3. Diperlukan model integrasi penegakan hukum Pilkada dengan cara merevitalisasi peran Bawaslu saat ini menjadi semi peradilan (quasi judiciary), yaitu Badan Penyelesaian Hukum Pemilihan (BPHP) atau semacan badan tunggal yang menyelesaiakan masalah pelanggaran hukum pilkada, berupa pelanggaran admnistrasi, sengketa Pilkada dan kode etik yang putusannya bersifat final dan mengikat. Maka fungsi pengawasan Bawaslu ditiadakan dan diperkuat aspek penindakan.

4. Penyelelesaian pidana Pilkada megikuti prosedur dalam sistem peradilan pidana yang telah ada dan untuk sengketa perselisihan hasil Pilkada dilakasnakan di Mahkamah Agung. 


\section{DAFTAR PUSTAKA}

\section{Buku}

Asshiddiqie, Jimly. (2002). Konsolidasi Naskah UUD 1945 Setelah Perubahan Keempat. Depok: Pusat Studi Hukum Tata Negara Fakultas Hukum Universitas Indonesia.

Chaerudin, Syaiful Ahmad Dinar, Syarif Fadillah. (2008). Strategi Pencegahan Dan

Penegakan Hukum Tindak Pidana Korupsi. Bandung:Refika Editama.

Electoral Integrity Group. Towards International Statement of The Principles of Electoral Justice (The Accra Guiding Principles).

Haris, Syamsuddin. (Editor). (2010). Pemilu Nasional Serentak 2019. Yogyakarta:

Pustaka Pelajar.

International IDEA. (2000). Demokrasi dan Konflik Yang Mengakar: Sejumlah Pilihan Untuk Negosiator, Seri Buku Pegangan Internasional IDEA. Jakarta.

Manullang, E. Fernando M. (2016). Legalisme, Legalitas dan Kepastian Hukum. Jakarta: Kencana Predana.

Nonet, Philippe \& Philip Selznick. (2003). Hukum Responsif, Pilihan di Masa Transisi. Penerjemah Rafael Edy Bosco. Jakarta: Ford Foundation-HuMa.

Posner, Richard A. (1999). Economic Analysis of Law (Edisi Keempat). London: Little Brown and Company.

Raharjo, Satjipto. (2007). Negara Hukum yang Membahagiakan Rakyatnya. Yogyakarta: Genta Press.

Rahardjo, Satjipto. (2008). Membedah Hukum Progresif. Jakarta: Penerbit Buku Kompas.

Riwanto, Agus. (2020). Kepastian Hukum Dan Tumpang Tindih Putusan Antar Lembaga Peradilan Dalam Perkara Pemilu. Dalam Ahsanul Minan dkk, Serial Evaluasi Penyelenggaraan Pemilu Serentak Tahun 2019: Perihal Penegakan Hukum Pemilu. Jakarta: Bawaslu RI.

Santoso, Topo dkk, (2006). Penegakkan Hukum Pemilu: Praktik Pemilu 2004, Kajian Pemilu 2009-2014. Jakarta: Perludem.

Satjipto Raharjo. (2012). Hukum Progresif Sebagai Dasar Pembangunan Ilmu Hukum Indononesia. Dalam Ahmad Gunawan (Penyunting), Menggagas Hukum Progresif Indonesia. Jakarta: Pustaka Pelajar.

Siregar, Fritz Edward. (2020). Pilihan Transformasi Badan Peradilan Khusus Pemilu. Dalam Ahsanul Minan Dkk, Serial Evaluasi Penyelenggaraan Pemilu Serentak Tahun 2019: Perihal Penegakan Hukum Pemilu. Jakarta: Bawaslu RI.

Soekanto, Soerjono. (2004). Faktor-Faktor Yang Mempengaruhi Penegakan Hukum Cetakan Kelima. Jakarta : Raja Grafindo Persada. 
Supriyanto, Didik. (2012). Penataan Kembali Sistem Pemilihan dalam Pemilukada. Dalam Achmad Dodi Haryadi, Demokrasi Lokal, Evaluasi Pemilukada di Indonesia. Jakarta: Konpress.

Zuhro, Siti. (2015). Urgensi Pemilihan Kepala Daerah Serentak. Dalam Saldi Isra dkk. Pemilihan Umum Serentak. Jakarta: PT. Rajawali Press.

\section{Jurnal}

Ellis, Antony. (2003). A Deterence Theory of Punishment, The Philosophical Quartely, Vol 33,No.212, Juli.

Fahmi, Khairul. (2016). Menelusuri Konsep Keadilan Pemilihan Umum Menurut UUD 1945, Jurnal Cita Hukum, Fakultas Syariah dan Hukum UIN Jakarta Vol.4 No.2.

Golder, Matt. (2006). Presidential Coattails and Legislative Fragmentation, in American Journal Political Science, vol, 11 Januari.

Samuels, Davids. (2000) Concurrent Election, Discordant Result: Presidentialism, Federalism, and Governance in Brazil, International Journal of Comparative Politics, Volume 33, Nomor 1.

Zoelva, Hamdan. (2013). Problematika Penyelesaian Sengketa Hasil Pemilukada oleh Mahkamah Konstitusi, Jurnal Konstitusi, Volume 10, Nomor 3, September.

\section{Website}

http://nasional.kompas.cm/read/2015/02/17/15003821/RUU.Pilkada .dan. Pemda.Disahkan.4.Fraksi.Setuju.Tanpa.Catatan, 17 Februari 2015, diakses tanggal 23 Juli 2020.

http://Augustmellar.multiply.journal.com/item/4, hal, 2. Diakses, 30 Juli 2020. https://nasional.kompas.com/read/2018/01/03/17391741/sengketa-pilkadadiprediksi-meningkat-akan-jadi-tugas-berat-bagi-mk.Diakses pada tanggal, 5 November 2020.

https://nasional.kompas.com/read/2018/07/12/07030091/kpu--ada-56sengketa-pilkada-yang-diajukan-ke-mahkamah-konstitusi. Diakses pada tanggal, 5 November 2020.

Nusantara, Abdul Hakim G. Mahkamah Konstitusi: Perspektif Politik dan Hukum, dalam perpustakaan.bappenas.go.id/lontar/file?file=digital/blob/F824/. Diakses pada tanggal, 6 Oktober 2019. 